\title{
Multilingual humour in audiovisual translation. Modern Family dubbed in Spanish
}

\author{
Noelia Marqués Cobeta \\ University of Zaragoza, Spain \\ nmarques@unizar.es
}

\begin{abstract}
This commentary aims to take up the gauntlet thrown down by Dore (2019) with her article about multilingual humour in the Italian dubbed version of the series Modern Family. She suggested that the scenes included in the article could be analysed in other languages, so it was an interesting proposal to carry out the analysis of the Spanish dubbed version, since the L2 in the source text coincides with the target text language. Thus, this fact makes the translation process an arduous activity in these language combinations. Multilingualism is therefore considered the central element in this study. It is a reflection of the current social movement and the increase of multi-ethnic communities worldwide. This fact leads to citizens who use their knowledge to assert their own identity; as a consequence, audiovisual producers are also aware of this situation and exploit this phenomenon. Modern Family is an example of this reality and introduces characters, like Gloria Delgado-Pritchett, as a role model to show an increasingly common tendency, the use of multilingual and multi-ethnic characters that reflect this new social situation. Thanks to the selected examples, we will see whether the use of multilingualism as a source of humour is also transmitted to the Spanish dubbed version, as it did in the Italian dubbed version studied by the abovementioned scholar.
\end{abstract}

Keywords: multilingualism, humour, dubbing, Modern Family, functional manipulation.

\section{Introduction}

This article aims to take up the gauntlet thrown down by Dore (2019) with her article published by this Journal in which she expressed her hope "that this work [could] foster future comparative analysis of the dubbed and subtitled version(s) of Modern Family in Italian and/or other languages" (2019: 67). It is therefore interesting to analyse the same examples the abovementioned scholar proposed in her article in order to confirm the tendency adopted when dubbing multilingual audiovisual texts into Spanish. Furthermore, part of the analysis and information is based on the author's doctoral thesis "The translation of humour in the American sitcom Modern Family" (2021). 
Although the use of multilingualism in audiovisual texts is increasingly common, as a reflection of the current migrant movements, its purposes can be diverse, from expressing or reinforcing the identity of migrants to humorous purposes.

This multilingual inter-play can be used to convey conflict, character configuration, spatial opposition, mimesis, and suspense management. Most importantly, interlingual misunderstandings and mistranslations can be used for comic effect by introducing what humour theorists would call an incongruity or conflict between different cognitive schemes.

(Delabastita \& Gutmas 2005: 18-24)

It is this last purpose on which this commentary is intended to focus in order to prove "how multilingual humour is dealt with in AVT" (Dore 2019: 53). After analysing the examples proposed, we will be able to discern the translation strategy in the Spanish language when facing multilingual humour.

\section{Multilingualism and humour}

Scholars are becoming more aware of the new phenomenon of heterolingualism in translation and they are focusing their studies on the description and evaluation of the current practices when transferring humour from the source to the target language.

Translation strategies have changed over the years and the tendency has varied from "flattening out and formalisation of authentic-sounding spoken language" (Heiss 2004: 213) to using multilingualism both in the source and in the target texts. The former option, "homogenisation", according to Sternberg (1981) or O'Sullivan (2007: 82-83), may simplify the translation process, although the text in the target language misses part of the original text's essence. On the contrary, the latter option, called "vernacular matching" by the prior scholars, although it means more difficulties for the translator, it offers new perspectives and enriches the target text, as it maintains the essence with which the text was originally conceived. It is then necessary to carry out what Dore (2019: 54) proposes to call "functional manipulation", i.e., to change or transform the target text so that it can transmit the same idea, essence and purpose as the source text.

Apart from the previous information, not every text that includes two or more languages can be considered a multilingual text since, according to De Bonis, these languages should play "a relevant role in the story and in the discourse" (De Bonis 2015: 52). This is one of the characteristics that defines the corpus selected for analysis - the American sitcom Modern Family.

\section{Modern Family}

This sitcom tells the story of a large and unconventional family. It is presented as a mockumentary, a term that comes from blending the words "mock" and "documentary", and is defined as a hybrid resource that merges comedy and fiction with the concept of a documentary. This feature confers on the series' originality and a new perspective when compared to other TV programmes.

It revolves around three different types of family (nuclear, step- and same-sex), where Jay Pritchett appears as the head of the unit. He has married his second young wife, Gloria, a Colombian immigrant. He is the father of one boy, Joe, born in this second marriage, the stepfather of Manny, the son from Gloria's previous marriage, and the father of two grown children, Claire and Mitchell, born in his first marriage. The rest of the characters are part of 
Claire's and Mitchell's families. Claire is married to Phil Dunphy and they are parents of three children: Haley, the beautiful and rebellious daughter; Alex, the smart and brilliant middle daughter; and Luke, the scatter-brained son, not forgetting that Phil is like a child himself. Mitchell is married to Cameron and they have adopted a Vietnamese child, Lily.

The variety of characters, their backgrounds and personalities make the series rich in humorous nuances, and it is considered a benchmark in the sitcom sector. Therefore, the series perfectly fits in the category of comedy. According to Delabastita \& Grutman (2005: 18), "interlingual misunderstandings and mistranslations can be used for comic effect (...), namely by bringing about what humour theorists would call an incongruity or conflict between different cognitive schemes", a resource that has been used and included in the series analysed. Heiss (2014: 15) also adds that "[i]n many comedies that depict a multi-ethnic society, the humour is expected to function as a binding element between the 'foreign' immigrant and the host culture of the immigration country". Modern Family clearly reflects this fact thanks to two of its main characters, Gloria Delgado-Pritchett and her son Manny. Thus, we agree with Dore, as she affirms that "[s]ince language variation for humorous purposes is essential for the story and discourse of the ST, it cannot be overlooked in translation" (Dore 2019: 57).

The following table shows how multilingualism is adapted in the Spanish dubbed version. It follows the distribution made by Dore (2019: 59), in which she compares the treatment of multilingualism in the Italian dubbed version:

Table 1. Language distribution in Modern Family and its Spanish dubbed version

\begin{tabular}{|c|c|c|}
\hline ST & TT & Transfer type \\
\hline English & Standard Spanish & L1 Q L2 \\
\hline Non-native English & $\begin{array}{c}\text { Spanish with a } \\
\text { Colombian accent }\end{array}$ & L1 mod L L2 $\bmod$ \\
\hline Spanish & $\begin{array}{c}\text { Spanish with a } \\
\text { Colombian accent }\end{array}$ & L2 Q L2 ${ }_{\text {mod }}$ \\
\hline
\end{tabular}

We find some differences in the Spanish dubbed version when we compare it with the Italian dubbed version. The reason is that Spanish is the language spoken in the target text and, therefore, it is the same language as the one Gloria sometimes speaks in the source text. This fact leads to another problem or obstacle that it is not considered in versions in which the target languages are different from any of the languages used in the source text: What is the translator able to do when humour is based on multilingualism but one of the languages of the source text is the main language of the target text?

First of all, it is necessary to explain the table above in order to understand the solutions the translator offered in order to translate the text on the one hand and, on the other, transfer the humour load from the source to the target text. We understand L1 as standard English spoken by all the native characters in the series and L2 as standard Spanish the characters speak in the target text. The difficulty arises when some characters, especially Gloria, communicate in their own way; namely, Gloria speaks English but with her Colombian accent, lexis and grammar. This is what we call $\mathrm{L}_{\text {mod }}$, as the language spoken has been modified or altered in order to show that the character is not a native speaker. The same scenario is found in the target text, when the character speaks Spanish with a Colombian accent and uses Colombian Spanish lexis and grammar; therefore, we call it $\mathrm{L} 2$ mod. The third and final case is when Spanish is used in the source text, that is, L2 in the original version. The solution given in the target text is that the 
character speaks the same language as in the source text but with a Colombian Spanish accent, lexis and grammar, hence $\mathrm{L} 2$ mod.

This solution adopted in the target text is not exempt from criticism since the image the characters portray in the original version does not correspond with the image the audience perceives in the dubbed version. This is the case of the character of Gloria. In this specific case, the translator chooses to maintain the same humorous elements and the same strategies from the source text to create humour and, therefore, the target audience perceives this character differently from the way the source audience does since there is a difference between how Gloria is originally depicted in the source text and how she appears in the target text. In the source text, Gloria is portrayed as an immigrant who struggles with the language since she does not speak in her mother tongue, as well as with some other problems she may have to face, related to traditions, customs, etc., as she lives a long way from her home country. However, this is not the case in the target version since Gloria appears talking in the same language as the rest of the characters in the series. The only difference is that she appears to come from a Latin American country, so the audience may suppose or accept that some of her expressions or her accent could be different from the rest.

The problem arises when the audience perceives that she does not just struggle with the language or cultural referents but she makes big and inexcusable grammar errors, or confuses simple sayings or expressions, apart from other mistakes related to mispronunciations, creating, therefore, a separate and artificial language variety. For these reasons, Gloria is not viewed as a common immigrant in the dubbed text, as she is in the original version, but as a woman who might be suspected of illiteracy or ignorance. The translation problems arisen from language errors made by this character are the result of the interference of the Spanish language Gloria sometimes speaks with the language of the country where the series takes place. However, the coincidence of the language Gloria and the rest of the characters speak in the target version makes the translation an arduous process. It is noteworthy that the resulting effect of the misuse of language leads to the depiction of an unintelligent or ignorant character.

After this clarification, we can now analyse the examples Dore (2019) proposed to justify the translation of multilingual humour in the Italian dubbed version of the series Modern Family.

\subsection{Analysis of the examples}

Table 2. Example 1

\begin{tabular}{|l|l|l|}
\hline ST & TT & Gloss \\
\hline Phil: What a beautiful dress. & Qué vestido tan bonito. & What a beautiful dress. \\
\hline Gloria: Thank you, Phil & Ay, gracias Phil. & Oh, thanks, Phil. \\
\hline $\begin{array}{l}\text { Phil: Okay, that's... } \\
\text { [Phil touches Gloria's dress] }\end{array}$ & Sí, es muy bonito... & Yes, it is very beautiful... \\
\hline $\begin{array}{l}\text { Claire: Phil, that's how she } \\
\text { says "Phil."Not "feel". "Phil". }\end{array}$ & $\begin{array}{l}\text { Quieto, se mira pero no } \\
\text { se toca, ¿vale? }\end{array}$ & Stop. Look but don't touch, ok? \\
\hline
\end{tabular}

The humour load in this scene is based on a linguistic element. In the source text, and according to Delabastita's classification (1996: 128), humour is achieved through paronymy, in this case, due to the use of two words that seem the same but show slight differences in both spelling and pronunciation. The pair of words are the proper name "Phil"/fil/ and the verb "to feel" /' fi:l/. The difference is found in the length of the vowel.

However, the linguistic element disappears in the target text. This text has been modified since the strategy of literal translation is not possible. According to the classification proposed 
by Delabastita (1996: 134), the outcome of the translated pun used is PUN > NON-PUN. Although the pun from the source text is not transmitted to the target version, the visual factor can be a tool through which the humorous effect can be maintained. In normal cases, nobody starts touching other people's clothes, so the image itself could be considered a resource to keep the humour load in the target version.

Although the last sentence in the source text explains the difference in pronunciation and the subsequent mistake, this sentence has been modified in the target text. There is no possible pun in Spanish that could be used as in the source text. Therefore, the translator chooses the strategy of creación discursiva (discursive creation) proposed by Hurtado (2001), so that the audience is able to understand what they see on the screen due to the addition of new information that did not exist in the source text. In the translated versions, images are more important than words, exactly the opposite to what happens in the source text, since language is the source of humour in the scene. The solution given is to use a Spanish idiom in order to explain that what Phil does is not correct "se mira pero no se toca" (look but do not touch). The expression is worth analysing since mothers in Spain usually say this to their children when they go into shops to prevent the children from touching and breaking articles. In this sense, Claire treats Phil as a child when she tells him off in the target text. However, this reference does not appear in the source text. It is also interesting to mention that Phil is attracted to Gloria and, in these first episodes of the series, makes little to hide it, as in this scene when he understands Gloria invites him to touch the dress and he does not miss the opportunity to touch her. Gloria and Claire are both aware of this, so this extra background information contributes to retaining part of the humour in this scene, while some of it is lost.

Table 3. Example 2

\begin{tabular}{|l|l|l|}
\hline ST & TT & Gloss \\
\hline $\begin{array}{l}\text { Gloria: Jay! This came for } \\
\text { you. }\end{array}$ & Jay, te ha llegado esto. & Jay, this came for you. \\
\hline $\begin{array}{l}\text { Jay: Oh, hi, honey. What is } \\
\text { it? }\end{array}$ & Ah, hola cariño. ¿Qué es? & Oh, hi, honey. What is it? \\
\hline $\begin{array}{l}\text { Gloria: I called your } \\
\text { secretary and told her to } \\
\text { order you some crackers } \\
\text { and those cheeses that you } \\
\text { like. The tiny little ones. }\end{array}$ & $\begin{array}{l}\text { Llamé a tu secretaria y le } \\
\text { dije que te mandara unas } \\
\text { qualletas saladas y esos que te gustan, los } \\
\text { pequeñitos. }\end{array}$ & $\begin{array}{l}\text { I called your secretary and told } \\
\text { her to send you some crackers } \\
\text { and those cheeses you like, the } \\
\text { little ones. }\end{array}$ \\
\hline Jay: Thanks. (..) & Gracias. & Thanks. \\
\hline Jay: What the hell is this? & Pero, ¿qué es esto? & But, what is this? \\
\hline $\begin{array}{l}\text { Gloria: I told you, Jay. I } \\
\text { called your secretary and } \\
\text { told her to order you a box } \\
\text { of baby cheeses. Oh, so } \\
\text { now that is my fault, too. }\end{array}$ & $\begin{array}{l}\text { Te he dicho, Jay. Llamé } \\
\text { te mandara una caja de } \\
\text { quesitos. Oh, y eso también } \\
\text { va a ser culpa mía. }\end{array}$ & $\begin{array}{l}\text { I told you, Jay. I called your } \\
\text { secretary and told her to send you } \\
\text { a box of little cheeses. Oh, and } \\
\text { this is also my fault. }\end{array}$ \\
\hline
\end{tabular}

The concept mentioned in the scene appears when Gloria asks Jay's secretary for some "little cheeses" and Jay opens the box and takes a "little Jesus". What the audience expects to see is not what they finally see on the screen so the humorous effect is created. It appears with the use of mimes with the pair of words "cheeses" /'t $\mathrm{fi}: \mathrm{z} \mathrm{Iz} /$ and "Jesus"/'dzi:z əs/, which share similar pronunciation. In this case, the humorous content disappears in the target text. In the Spanish version, any trace of humorous allusion is non-existent, as Gloria says "quesitos" (little cheeses) but what Jay takes is a "niño Jesús" (little Jesus), concepts which are completely different and 
not related in any way. Therefore, and according to the classification proposed by Delabastita (1996: 134), the outcome of the translated pun is PUN > NON-PUN. It could be considered that humour is preserved, as what the audience expects to see is not what they see. This incongruity thus leads to a humorous moment.

Table 4. Example 3

\begin{tabular}{|c|c|c|}
\hline ST & TT & Gloss \\
\hline $\begin{array}{l}\text { Jay: Honey, look. English } \\
\text { is your second language. } \\
\text { You're doin' great. }\end{array}$ & $\begin{array}{l}\text { Cariño, mira, en tu país } \\
\text { habláis distinto, lo estás } \\
\text { haciendo genial. }\end{array}$ & $\begin{array}{l}\text { Honey, look, in your country, } \\
\text { you speak differently, you're } \\
\text { doing great. }\end{array}$ \\
\hline $\begin{array}{l}\text { Gloria: Yeah, you're not } \\
\text { helping by protecting my } \\
\text { feelings. I want you to be } \\
\text { honest with me. (...) }\end{array}$ & $\begin{array}{l}\text { Ay, no me ayudas si me } \\
\text { proteges siempre. } \\
\text { Quiero que seas sincero } \\
\text { conmigo. }\end{array}$ & $\begin{array}{l}\text { Ey, you don't help me if you are } \\
\text { always protecting me. I want you } \\
\text { to be honest with me. }\end{array}$ \\
\hline $\begin{array}{l}\text { Jay: Last night you said we } \\
\text { live in a "doggy-dog" } \\
\text { world. }\end{array}$ & $\begin{array}{l}\text { Anoche dijiste que } \\
\text { vivíamos en un mundo "de } \\
\text { puerros". }\end{array}$ & $\begin{array}{l}\text { Last night you said that we lived } \\
\text { in a "leek" world. }\end{array}$ \\
\hline Gloria: So? & ¿Y qué? & And so? \\
\hline $\begin{array}{l}\text { Jay: It's "dog-eat-dog" } \\
\text { world. }\end{array}$ & Se dice mundo "de perros". & It's a "dog v \\
\hline $\begin{array}{l}\text { Gloria: (...) What else do I } \\
\text { say wrong? }\end{array}$ & ¿Qué más digo mal? & What else do I say wrong? \\
\hline $\begin{array}{l}\text { Jay: Well, it's not } \\
\text { "blessings in the skies". It's } \\
\text { "blessings in disguise". }\end{array}$ & $\begin{array}{l}\text { Aquí "agarrarse con } \\
\text { alguien" no se entiende } \\
\text { como "pelear". }\end{array}$ & $\begin{array}{l}\text { Here, "to hold on to somebody" } \\
\text { isn't understood as "to fight". }\end{array}$ \\
\hline Gloria: What else? & ¿Qué más? & What else? \\
\hline $\begin{array}{l}\text { Jay: "Carpal tunnel } \\
\text { syndrome" is not "carpool } \\
\text { tunnel syndrome". }\end{array}$ & $\begin{array}{lrr}\text { Nosotros no nos } & \text { damos } \\
\text { "albricias" } & & \text { sino } \\
\text { "sorpresas". } & & \\
& & \end{array}$ & $\begin{array}{l}\text { We don’t give "gifts" but } \\
\text { "surprises". }\end{array}$ \\
\hline Gloria: And what else? & ¿Y qué más? & And what else? \\
\hline $\begin{array}{l}\text { Jay: It's not "vo-lump- } \\
\text { tuous". }\end{array}$ & Aquí no se dice "pachu-" & Here we don't say "vo-lomp-" \\
\hline $\begin{array}{l}\text { Gloria: Okay, enough. I } \\
\text { know that I have an accent, } \\
\text { but people understand me } \\
\text { just fine. }\end{array}$ & $\begin{array}{l}\text { Bueno, ya vale. Sé que no } \\
\text { hablo como ustedes, pero } \\
\text { me entienden } \\
\text { perfectamente. }\end{array}$ & $\begin{array}{l}\text { Ok, enough. I know I don't speak } \\
\text { like you, but people understand } \\
\text { me perfectly well. }\end{array}$ \\
\hline
\end{tabular}

In the source text, Jay mentions that "English is your second language", whereas in the target text he says "en tu pais habláis distinto" (in your country, you talk differently), remarking that in her country, they have different words, expressions or accents. However, Jay does not mention that she speaks another language.

As far as specific mistakes are concerned, the following concepts are discussed:

1. "Doggy-dog-world" instead of "dog-eat-dog world". The error is based on a mimetic phrase since the pronunciation of both expressions is very similar or almost the same, although the words in them are different. As Nash (1985: 140) states, mimetic phrases are based on well-known phrases or expressions that include some changes for humorous purposes. The solution given in the target text is "mundo de puerros" (leeks' world) instead of "mundo de perros" (dogs' world). In this case, the resource used is also a 
mimetic phrase since it is a well-known phrase which is mistakenly expressed because of the misuse of a word, in this example "puerros", as the character does not know or mistakenly uses the Spanish expression since "puerros" and "perros" are considered mimes. The expression has been adapted to the target language for the audience to understand and recognise it but maintains the idea of the original.

2. "Blessings in the sky", instead of "blessings in disguise". As in the previous example, the error is based on a mimetic phrase since both the expression used by the character and the correct one have a similar pronunciation, although the words that form them are different. The solution given in the target text is "agarrarse con alguien" (fight), instead of "pelear" (fight). In this case, the translator also opts to change the expression in order to transmit the information from the source text. The result obtained in the translation is completely different from the one in the source text since the translator chooses a Latin American expression rather than a Castilian expression. This solution can be understood since the character comes from a Latin American country, Colombia, so the translator has intended to include an expression from her country. In this specific example, the fourth outcome of the translated pun defined by Delabastita (1996: 134) is applied, PUN $>$ ZERO, since the pun disappears in this version.

3. "Carpool tunnel syndrome", instead of "carpal tunnel syndrome". The error is based on a mimetic phrase due to similar pronunciation of the terms "carpool" /'ka:rpu:l/ and "carpal" /'ka:rpl/. The solution given in the target text is "no nos damos albricias" (we don't give gifts), instead of "sorpresas" (surprises). In this case, the strategy used is completely different to the one used in the source text, and the translator chooses to use another Latin American expression rather than a Castilian expression to transmit the information from the source text. The translation adapts the information in the target text, although, in this specific example, the fourth outcome of the translated pun defined by Delabastita (1996: 134) is applied, PUN > ZERO, since the pun disappears in this version.

Table 5. Example 4

\begin{tabular}{|l|l|l|}
\hline ST & TT & Gloss \\
\hline $\begin{array}{l}\text { Manny: And one time she } \\
\text { says: "Don't choke or I'll } \\
\text { give you the Hindenburg } \\
\text { maneuver." }\end{array}$ & $\begin{array}{l}\text { Ah, y una vez dijo: "Si te } \\
\text { atragantas, te hago la } \\
\text { maniobra de Hindenburg". }\end{array}$ & $\begin{array}{l}\text { Ah, and once she said: "If you } \\
\text { choke, I'll give you the } \\
\text { Hindenburg maneuver." }\end{array}$ \\
\hline $\begin{array}{l}\text { Cameron: One time she } \\
\text { caught me staring off and } \\
\text { she goes "Cam, what's } \\
\text { wrong? You look like a } \\
\text { deer in a headlice!" }\end{array}$ & $\begin{array}{l}\text { una vez me pilló } \\
\text { iqué te pasa, chico? Estás } \\
\text { un poco achicopalado". }\end{array}$ & $\begin{array}{l}\text { And once she caught me staring at } \\
\text { her and she said: "Cam, what's } \\
\text { going on, boy? You look a bit } \\
\text { depressed." }\end{array}$ \\
\hline $\begin{array}{l}\text { Phil: If you tell her she } \\
\text { doesn't have a choice, } \\
\text { she'll tell you "don't you } \\
\text { give me an old tomato." }\end{array}$ & $\begin{array}{l}\text { Si le dices que estás } \\
\text { preocupado, te dice: "no } \\
\text { me vengas con esas } \\
\text { afugias". }\end{array}$ & $\begin{array}{l}\text { If you tell her you're worried, she } \\
\text { says: "don't come to me with these } \\
\text { predicaments." }\end{array}$ \\
\hline $\begin{array}{l}\text { Gloria: OK! Enough! You } \\
\text { try speaking in another } \\
\text { language! Everybody out } \\
\text { of my house! }\end{array}$ & $\begin{array}{l}\text { Bueno, iya vale! Ya me } \\
\text { gustaría veros hablando en } \\
\text { Colombia. iTodo el mundo } \\
\text { fuera de mi casa! }\end{array}$ & $\begin{array}{l}\text { Ok, enough! I would like to see } \\
\text { you speaking in Colombia. } \\
\text { Everybody out of my house! }\end{array}$ \\
\hline
\end{tabular}


When the source text is analysed, different errors related to some typical English expressions can be detected. However, the strategies adopted in the Spanish dubbed version are different from those in the source text:

1. "I'll give you the Hindenburg maneuver". In the source text, Gloria confuses the expression "Heimlich maneuver" with the Hindenburg zeppelin disaster that occurred in 1937 and caused 35 deaths from the 97 people onboard. The audience may recognise this mistake due to the difficulty that these two German words entail, although it is still funny for the audience to see how the character confuses the two concepts. In the target text, the strategy adopted coincides with the source text and the character also mixes the two abovementioned ideas. In order to understand this joke, the audience should be capable of recognising the two notions and discerning that they are two different events.

2. "You look like a deer in a headlice". In the source text, Gloria confuses this expression with the correct one "You look like a deer in headlights". The joke in this case is based on a malapropism (incorrect use of paronymous words), according to Nash (1985), due to the similarities the invented word "headlice" /hedlais/ shares with the correct one "headlights" /'hedlarts/. In the target text, however, the resource used is the adjective "achicopalado" (depressed). This is a Latin American word that has been chosen due to the fact that Gloria is a Latin American immigrant. In this case, the rest of the characters make fun of her, not because she makes a linguistic error but because she uses a foreign expression. However, it is interesting to mention that "achicopalado" is a typical adjective used in Honduras and Mexico, whereas Gloria comes from Colombia.

3. "Don't you give me an old tomato". The joke, in this case, is based on the similarities that exist between the pronunciation of "old tomato" /ould to'meitoo/ and "ultimatum" /, sltı'mertəm/. This paronymy, according to Delabastita (1996), creates confusion and the resulting joke. However, in the target text, the resource is based on the use of another Latin American noun "afugias" (predicaments). This solution does not lead to the creation of a humorous moment, as in the source text, since the translator's strategy was to use a Latin American word instead of a Castilian word.

Table 6. Example 5

\begin{tabular}{|l|l|l|}
\hline ST & TT & Gloss \\
\hline Gloria: Hola, Jay. & Hola, Jay. & Hello, Jay. \\
\hline Jay: Where are you? & ¿Dónde estás? & Where are you? \\
\hline $\begin{array}{l}\text { Gloria: I have Manny in the } \\
\text { carpool, and we're going to } \\
\text { the dropout. }\end{array}$ & $\begin{array}{l}\text { Llevo en el coche a } \\
\text { Manny y vamos al punto } \\
\text { limpio. }\end{array}$ & $\begin{array}{l}\text { I am with Manny and we go to the } \\
\text { Clean Point. }\end{array}$ \\
\hline $\begin{array}{l}\text { Jay: Dropout. You mean that } \\
\begin{array}{l}\text { Eddie kid? Yeah, he's a } \\
\text { moron. }\end{array}\end{array}$ & $\begin{array}{l}\text { ¿El punto limpio? ¿Lo } \\
\text { dices por Eddie? Sí, es } \\
\text { un poco guarro. }\end{array}$ & $\begin{array}{l}\text { Clean Point? You say it because } \\
\text { of Eddie? Yes, he's a bit slob. }\end{array}$ \\
\hline $\begin{array}{l}\text { Gloria: No, the dropout, } \\
\text { where you drop the kids in the } \\
\text { school. }\end{array}$ & $\begin{array}{l}\text { No, el punto limpio, } \\
\text { donde dejas a los niños } \\
\text { en el cole. }\end{array}$ & $\begin{array}{l}\text { No, the Clean Point, where you } \\
\text { leave the kids at school. }\end{array}$ \\
\hline $\begin{array}{l}\text { Manny: She means “drop- } \\
\text { off”. }\end{array}$ & $\begin{array}{l}\text { Quiere decir punto de de } \\
\text { recogida. }\end{array}$ & She means “drop-off”. \\
\hline $\begin{array}{l}\text { Gloria: That's what I said. } \\
\text { (...) [Talking about Halloween } \\
\text { costumes] }\end{array}$ & $\begin{array}{l}\text { Eso he dicho. (...) } \\
\text { Tú vas a ir de gárgara y yourde } \\
\text { yo voy de bruja } \\
\text { supermalvada. (...) }\end{array}$ & $\begin{array}{l}\text { That's what I said. (...) } \\
\text { You'm going to be a superevil witch. } \\
\text { (...) }\end{array}$ \\
\hline
\end{tabular}




\begin{tabular}{|l|l|l|}
\hline $\begin{array}{l}\text { You're going to be a gargle and } \\
\text { I'm going to be an evil village } \\
\text { bruja. (...) }\end{array}$ & & \\
\hline $\begin{array}{l}\text { Manny: She means } \\
\text { "gargoyle". }\end{array}$ & Quiere decir "gárgola". & She means "gargoyle". \\
\hline Gloria: That's what I said. & Eso he dicho. & That's what I said. \\
\hline
\end{tabular}

The humour in this scene is based on the linguistic element, due to the language error made by one of the characters. In the original version, Gloria confuses the phrasal verb "drop off" with another phrasal verb "drop out". This is a very frequent problem in foreigners since changing the preposition can represent a complete change in meaning of the verb, leading to confusion. With the use of this contact and blend, according to the classification proposed by Nash (1985), the source text creates a humorous scene in which the entire speech event is misunderstood. This mistake can be considered a common one since the only difference is the preposition, and both prepositions, the one she uses and the correct one, start with the same letter.

In the dubbed version, the linguistic element is transmitted with the use of the expression "punto limpio" (waste facility), instead of "punto de recogida" (meeting point). In this case, the translator chooses to adapt the source text to the target audience. The translation approach of adaptation to the target language and culture creates another humorous effect in the dubbed version by using the word "punto" (point) as a shared word in both the correct and mistaken expressions. The translator tries to transmit the character's mistake by the misuse of an expression in relation to the context where it is used since "punto de recogida" is the place where parents leave and pick up their children at school and "punto limpio" is the place where people leave old things when they are unusable. The idea of leaving children because they are "useless" is what creates the intended humorous effect due to malapropism. The audience may understand that, in the original version, the character makes this mistake since she talks in her second language; however, this option is not so understandable in the dubbed version since the character talks in her mother language.

Another error found in the original version is when Gloria mispronounces the word "gargoyle" /'ga:rgoıl/ (gárgola) and ends up saying "gargle" /'ga:rgəl/ (gárgara) instead. Paronymy has been used to create the humorous effect since the two words present slight differences in both spelling and pronunciation, but the mistake can be understood due to the similarities they also share.

In the dubbed version, the solution given is to say "gárgara", instead of "gárgola", words that, as in the original version, share some similarities but show slight differences in their spelling and pronunciation.

As regards the word "bruja" (witch) in the source text, it is used in the same way in the dubbed version but, as the same language is spoken, there is nothing remarkable to say about it.

Table 7. Example 6

\begin{tabular}{|l|l|l|}
\hline ST & TT & Gloss \\
\hline $\begin{array}{l}\text { Manny: Jay shocked himself } \\
\text { twice. }\end{array}$ & $\begin{array}{l}\text { Jay se ha llevado dos } \\
\text { calambres. }\end{array}$ & Jay shocked himself twice. \\
\hline Jay: Ok, Manny. & Vale, Manny. & Ok, Manny. \\
\hline Manny: Well, I warned him. & Se lo he advertido, pero... & I warned him but... \\
\hline $\begin{array}{l}\text { Jay: Yep, he's been a big } \\
\text { help. }\end{array}$ & Sí... me ayuda mucho. & Yes... he is helping me a lot. \\
\hline $\begin{array}{l}\text { Gloria: Look at you two with } \\
\text { your private jokes already. }\end{array}$ & $\begin{array}{l}\text { Ya están ustedes dos con } \\
\text { sus bromitas particulares. }\end{array}$ & $\begin{array}{l}\text { You already have your own } \\
\text { jokes. You're like Salazar and El }\end{array}$ \\
\hline
\end{tabular}




\begin{tabular}{|c|c|c|}
\hline $\begin{array}{l}\text { You're a regular Salazar and } \\
\text { El Oso. [Off screen] It's a } \\
\text { very big comedy team in } \\
\text { Colombia. [Onscreen; } \\
\text { documentary-style interview] } \\
\text { El Oso is always hitting } \\
\text { Salazar in the head with the } \\
\text { ladder and things. [Off } \\
\text { screen] And sometimes they } \\
\text { wear dresses. Hmm. } \\
\text { [Onscreen] They make you } \\
\text { laugh, but they also make you } \\
\text { think. }\end{array}$ & $\begin{array}{l}\text { Son igualitos que Salazar } \\
\text { y El Oso. Es un dúo } \\
\text { cómico muy famoso en } \\
\text { Colombia. El Oso } \\
\text { siempre está dándole a } \\
\text { Salazar con un mazo y } \\
\text { otras cosas. Y a veces se } \\
\text { ponen vestidos de mujer. } \\
\text { Mmm. Te hacen reír, pero } \\
\text { también te hacen pensar. }\end{array}$ & $\begin{array}{l}\text { Oso. It's a very famous comedy } \\
\text { duo in Colombia. El Oso is } \\
\text { always hitting Salazar with a } \\
\text { mallet and other things. And } \\
\text { sometimes they wear female } \\
\text { dresses. Hmm. They make you } \\
\text { laugh, but they also make you } \\
\text { think. }\end{array}$ \\
\hline
\end{tabular}

Apart from the marked accent of the character that Dore (2019: 66) explained, i.e., the rhotic /r/ in "already"; the silent, non-rhotic / $\mathrm{r}$ / in "ladder"; or the plosive /b/ for the English voice fricative /v/ in "very", there are no other examples of verbal humour in the scene. In the target text, the only differences that could be found when the two texts are compared is that, in the dubbed version, Gloria specifies that El Oso uses a mallet to hit Salazar in his head "El Oso siempre está dándole a Salazar con un mazo y otras cosas", instead of choosing a literal translation with the use of "the ladder and things." Another interesting point is that, in the target text, Gloria specifies that " $Y$ a veces se ponen vestidos de mujer" (and sometimes they wear female dresses) when, in the source text, she only mentions that "sometimes they wear dresses". Dresses are a type of clothing specifically designed for women, so the translator, due to the insertion of "de mujer" (female), includes redundant and repetitive information in the target text.

Table 8. Example 7

\begin{tabular}{|c|c|c|}
\hline ST & TT & Gloss \\
\hline $\begin{array}{l}\text { Gloria: You know, this } \\
\text { part of town may be very } \\
\text { rough, but the people here, } \\
\text { Cameron... The best! } \\
\text { [They see Cameron's car } \\
\text { on four cement blocks and } \\
\text { missing its wheels] }\end{array}$ & $\begin{array}{l}\text { Sabes, esta parte de la } \\
\text { ciudad es muy dura, pero la } \\
\text { gente de por aquí, } \\
\text { Cameron, ¡lo mejor! }\end{array}$ & $\begin{array}{l}\text { You know, this part of town is very } \\
\text { tough, but people here, Cameron, } \\
\text { the best! }\end{array}$ \\
\hline $\begin{array}{l}\text { Cameron: I'm pretty sure } \\
\text { I had wheels when I } \\
\text { parked here. }\end{array}$ & $\begin{array}{l}\text { Creo que tenía ruedas } \\
\text { cuando he aparcado. }\end{array}$ & $\begin{array}{l}\text { I think it had wheels when I } \\
\text { parked. }\end{array}$ \\
\hline $\begin{array}{l}\text { Gloria: } A Y-A Y \text { ! Who did } \\
\text { this?... Who did this? You } \\
\text { coward sons of bitches! } \\
\text { [banging her bag against } \\
\text { the windows of a nearby } \\
\text { building] You scare? You } \\
\text { scare to show your faces? } \\
\text { Little girls... }\end{array}$ & $\begin{array}{l}\text { ¡Ay, ay, ay! ¿Quién ha } \\
\text { sido? ¿Quién ha sido? } \\
\text { ¡Cobardes, hijos de puta! } \\
\text { ¿Qué, qué? ¿Tenéis miedo? } \\
\text { ¿Os da miedo dar la cara, } \\
\text { eh? }\end{array}$ & $\begin{array}{l}\text { Ay, ay, ay! Who did this? Who did } \\
\text { this? Cowards, sons of bitches! } \\
\text { What, what? Are you scared? Are } \\
\text { you scared of showing your faces, } \\
\text { eh? }\end{array}$ \\
\hline
\end{tabular}

Humour in this scene is based on the contrast between what is said and what the audience sees. Gloria says that people living in the neighbourhood are good neighbours, but, after this 
statement, the audience sees that Cameron's car does not have its four wheels and that they have been stolen. Therefore, this incongruity creates humorousness in the scene. In the same way, humour in the target text is also based on the contrast between what Gloria says and what is seen on the screen, but it is not related to verbal humour either in the source or the target text.

Apart from the analysis of these two last scenes, it is important to remark that Dore (2019: 66) uses Examples 6 and 7 to show that not only the Italian dubbing team has skilfully used the Spanish accent but also added Spanish words in the target text, when there were none in the source text, thus perhaps compensating for losses somewhere in the text or to increase the target text's humour potential.

\section{Conclusions}

After analysing the seven examples proposed by Dore (2019) in her article about multilingual humour in the Italian dubbed version of Modern Family, we have detected some similarities and differences in the Spanish dubbed version of the same series and scenes.

It was very interesting to be able to compare how the same scenes of the same series have been modified and adapted depending on the language and the country where they were broadcast. Furthermore, in Spain, the target language complicates the translation process since the L2 in the source text is the same as the target text language where it is broadcast.

However, apart from the difficulties arisen due to this fact, humour nuances have been successfully transmitted to the Spanish dubbed version in the majority of cases, although the resources used are different from the ones in the source text in some examples. From the seven examples analysed, in Examples 3, 4 and 5, the humour load is transmitted with the use of verbal humour in the same way as in the source text. However, examples 1, 2, 6, and 7 do not use verbal humour in order to transfer the humorous component from the source text. In these specific four cases, Examples 1, 2 and 7 base their humour on the visual element since what is said and what the audience sees on the screen leads to an incongruity that creates humour. Regarding Example 6, we do not find any kind of humour in this scene, so humour load is lost in the Spanish dubbed version.

According to the previous theoretical considerations, we could state that the language has been flattened out and suffered the process of "homogenisation" (Sternberg 1981; O'Sullivan 2007) in Examples 1, 2, 6, and 7, whereas in Examples 3, 4 and 5, "vernacular matching" has been included in the dubbed version.

It is also important to reiterate that the target text pictures Gloria as an uneducated and ignorant woman, which is not the case in the source text since she is portrayed as an immigrant who struggles with the English language and some expressions or customs. Therefore, this is to show that although very attractive, Gloria is not a bimbo in the source text, as it seems to be in the Spanish target text.

\section{References}

Delabastita, D. (1996). 'Introduction', in Delabastita, D. (ed.), The Translator: Studies in Intercultural Communication vol. 2, Manchester: St. Jerome, pp. 127-139.

Delabastita, D. \& Grutman, R. (2005). 'Introduction: Fictional representations of multilingualism and translation', in Delabastita, D. \& Grutman, R. (eds.), Fictionalising

Translation and Multilingualism, Linguistica Antverpiensia 4, pp. 11-34.

De Bonis, G. (2015). 'Translating multilingualism in film: A case study on Le concert'. New Voices in Translation Studies 12, pp. 50-71. 
Dore, M. (2019). 'Multilingual humour in audiovisual translation. Modern Family dubbed in Italian. The European Journal of Humour Research 7 (1), pp. 52-70.

Heiss, C. (2014). 'Multilingual films and integration? What role does film translation play?', in Abend-David, D. (ed.), Media and Translation: An Interdisciplinary Approach, London: Bloomsbury.

Hurtado, A. (2001). Traducción y traductología. Madrid: Cátedra.

Marqués Cobeta, N. (2021). The Translation of Humour in the American Sitcom 'Modern Family'. PhD thesis. Faculty of Arts, University of Zaragoza.

Meylaerts, R. (2006). 'Heterolingualism in/and translation. How legitimate are the Other and his/her language? An introduction.' Target 18 (1), pp. 17-47.

Monti, S. (2016). 'Reconstructing, reinterpreting and renarrating code-switching in the Italian dubbed version of British and American multilingual films'. Altre Modernità, Numero speciale, pp. 68-91.

Nash, W. (1985). The Language of Humor. London/New York: Longman.

O'Sullivan, C. (2007). 'Multilingualism at the multiplex: a new audience for screen translation?', Linguistica Antverpiensia 6, pp. 81-95.

Sternberg, M. (1981). 'Polylingualism as reality and translation as mimesis'. Poetics Today 2 (4), pp. 221-239. 